\title{
ANALISIS REGULASI PENGEMBANGAN PRODUK UNGGULAN SUMATERA UTARA BERBASIS DESA
}

\section{REGULATION ANALYSIS OF FEATURED PRODUCT DEVELOPMENT OF NORTH SUMATRA VILLAGE BASED}

\author{
Afri Winata Lubis ${ }^{1}$, Lailan Tawwila ${ }^{2}$, Syafri, Jonni Sitorus ${ }^{3}$ \\ Badan Penelitian dan Pengembangan Provinsi Sumatera Utara \\ Diterima: Oktober 2021 Disetujui: Oktober 2021 Dipublish: Oktober 2021
}

*Corresponding Email: Afriwinata@gmail.com

\begin{abstract}
ABSTRAK
Di Sumatera Utara kawasan pedesaan merupakan kawasan yang mendominasi potensi luar biasa, seperti pertanian, wisata, kuliner dan berbagai hasil kerajinan masyarakat. Jika dikelola dan dikembangkan secara maksimal dapat mendorong percepatan pembangunan di Sumatera Utara. Fokus membangun desa dan menata kota tersebut sudah disiapkan malalui langkah-langkah konkret yang harus ditempuh Pemerintah Provinsi Sumatera Utara adapun pengembangan industri unggulan di Provinsi Sumatera Utara fokus pada produk unggulan per Kabupaten/Kota. Namun sayangnya perangkat desa ataupun pemerintah daerah belum maksimal dalam menindaklanjuti programprogram produk unggulan. Adapun yang menjadi tujuan dari penelitian ini tentang regulasi pengembangan produk unggulan daerah ini adalah diselaraskan dengan tujuan pembangunan industri berbasis produk unggulan di Provinsi Sumatera Utara dengan tetap mengacu kepada regulasi yang ditetapkan oleh Menteri Dalam Negeri yaitu meningkatkan pertumbuhan sektor industri produk unggulan Sumatera Utara berbasis desa, meningkatnya nilai ekspor produk industri tanpa migas, meningkatnya nilai investasi di sektor industri tanpa migas, meningkatnya produksi dan nilai tambah potensi daerah. Metode yang digunakan pada penelitian ini melalui pendekatan partisipatif melalui interview untuk menganalisis pemahaman pemerintah daerah tentang bagaimana regulasi atau peraturan Produk Unggulan Daerah berbasis Desa dapat bermanfaat sesuai dengan tujuan dan sasaran penyusunannya. Adapun hasil penelitian menunjukkan bahwa Regulasi tentang pengembangan produk unggulan Sumatera Utara masih mengacu pada Peraturan Menteri Dalam Negeri Republik Indonesia dan juga pemahaman Pemerintah Daerah sesuai dengan indikator pernyataan yang diberikan dan juga masih belum terjadinya koordinasi antar Organisasi Perangkat Daerah (OPD) sehingga beberapa informasi yang diberikan masih belum dipahami.
\end{abstract}

Kata kunci: Desa; Produk Unggulan; Regulasi

\begin{abstract}
In North Sumatra, rural areas are areas that dominate extraordinary potential, such as agriculture, tourism, culinary and various community handicrafts. If it is managed and developed optimally, it can accelerate development in North Sumatra. The focus of developing the village and managing the city has been prepared through concrete steps that must be taken by the North Sumatra Government, while the development of leading industries in North Sumatra Province focuses on superior products per regency/city. However, unfortunately the village or local government official has not been maximal in following up on superior product programs. As for the purpose of this research on regulations for the development of superior regional products is to be aligned with the objectives of developing superior product-based industries in North Sumatra Province by still referring to the regulations set by the minister of home affairs, that are increase the growth of the village-based leading product industry sector in North Sumatra, increasing the export value of industrial products without oil and gas, increasing the value of investment in the industrial sector without oil and gas, increasing production and value-added regional potential. The method used in this study was a participatory approach through interviews to analyze local government understanding of how village-based regional superior product regulations or regulations can be useful in accordance with the goals and objectives of their preparation. The results of the research show that the regulations regarding the development of superior products of North Sumatra still refer to the Regulation of the Minister of Home Affairs of the Republic of Indonesia and also the understanding of the local government according to the statement indicators given and there is still no coordination between Regional Officer Organization so that some of the information provided is still not understood.
\end{abstract}

Keywords: Featured Products; Regulation; Village 


\section{PENDAHULUAN}

Di Sumatera Utara kawasan pedesaanlah yang mendominasi potensi yang luar biasa, seperti pertanian, wisata, kuliner dan berbagai hasil kerajinan masyarakat. Jika dikelola dan dikembangkan secara maksimal dapat mendorong percepatan pembangunan di Sumatera Utara, khususnya bagi masyarakat Desa sendiri. Jika desa-desa di Sumatera Utara maju dan masyarakatnya sejahtera, maka tidak akan ada lagi yang berbondong-bondong mencari pekerjaan di kota dengan tujuan hidup layak dan disegani orang (Setiawan, 2012) sehingga akan lebih mudah untuk menata kota. Sesuai dengan Rencana Pembangunan Jangka Menengah Daerah (RPJMD) Sumatera Utara 2018-2023 (Gubernur sumatera utara, 2019) yaitu Gubernur dan Wakil Gubernur Sumatera Utara bertekad untuk mewujudkan Sumatera Utara bermartabat lewat Konsep Membangun Desa Menata Kota.

Fokus membangun desa dan menata kota tersebut sudah disiapkan malalui langkahlangkah konkret yang harus ditempuh Pemerintah Provinsi Sumatera Utara (Pemprov Sumatera Utara) lima tahun ke depan, salah satunya dengan membuat (Gubernur Sumatera Utara, 2018) Peraturan No. 4 Tahun 2018 tentang Rencana Pembangunan Industri Provinsi Sumatera Utara Tahun 2018-2038. Adapun pengembangan industri unggulan di Provinsi Sumatera Utara, berdasarkan pada produk unggulan per Kabupaten/Kota. Untuk mendukung pengembangan produk unggulan per kabupaten/kota tersebut Provinsi Sumatera Utara masih mengacu pada peraturan Menteri Dalam Negeri Republik Indonesia Nomor 9 Tahun 2014 tentang Pedoman Pengembangan Produk Unggulan Daerah, dan di dalam peraturan tersebut disebutkan pada poin 1 bahwa pengembangan produk unggulan daerah dilakukan oleh pemerintah daerah dan masyarakat. Apabila pengembangan produk unggulan tersebut berbasis desa, maka sudah tentu pihak yang terlibat mulai dari pemerintahan Desa sampai kepada pemerintahan provinsi, dan masyarakat desa setempat melalui perencanaan, pengorganisasian, pembiayaan, pengawasan, pengendalian, dan evaluasi kegiatan.

Meskipun dalam pengembangan wilayah tidak disebutkan secara khusus desa yang menjadi basis produk unggulan untuk masing-masing daerah, namun tentunya setiap perangkat daerah dianggap telah mampu bersinergi untuk mengangkat produk-produk unggulan desanya sehingga ujungnya akan menjadi produk unggulan dari provinsi Sumatera Utara. Dan yang menjadi tujuan dari penelitian ini yaitu pemerintah mampu memahami tentang ketepatan regulasi pengembangan produk unggulan kabupaten/kota di Sumatera Utara, pemerintah memahami potensi disharmoni peraturan produk unggulan kabupaten/kota Provinsi Sumatera Utara, pemerintah memahami kesesuaian norma dan ketepatan azas tata kelola produk unggulan, dan memahami efektivitas pelaksanaan regulasi (sumber daya manusia, kesesuaian kultur, pelayanan, pemanfaatan sumber daya alam) produk unggulan kabupaten/kota di Provinsi Sumatera Utara.

Produk Unggulan Daerah yang selanjutnya disingkat PUD Menurut Peraturan Menteri Dalam Negeri Nomor 9 Tahun 2014 merupakan produk, baik berupa barang maupun jasa, yang dihasilkan oleh koperasi, usaha skala kecil dan menengah yang potensial untuk dikembangkan dengan memanfaatkan semua sumber daya yang dimiliki oleh daerah baik sumber daya alam, sumber daya manusia dan budaya lokal, serta mendatangkan pendapatan bagi masyarakat maupun pemerintah yang diharapkan menjadi kekuatan ekonomi bagi daerah dan masyarakat setempat sebagai produk yang potensial memiliki daya saing, daya jual, dan daya dorong menuju dan mampu memasuki pasar global. Sedangkan menurut Dedidwitagama dalam (Khoirul ahmadi, 2012) menjelaskan bahawa keunggulan lokal atau produk unggulan daerah merupakan hasil bumi, kreasi seni, tradisi, budaya, pelayanan, jasa, sumber daya alam, sumber daya alam dan manusia atau lainnya yang menjadi keunggulan suatu daerah. Potensi suatu daerah harus bisa 
ditingkatkan nilainya agar bisa menjadi produk/jasa yang bernilai tinggi yang bisa menambah penghasilan setiap daerah. Potensi daerah merupakan potensi sumber daya tertentu yang dimiliki suatu daerah sehingga Peranan produk unggulan sangat krusial karena merupakan produk yang mampu memberi kontribusi terbesar terhadap perolehan penerimaan daerah, terutama jika dilihat kontribusinya terhadap PAD-PDRB. Hal ini terlihat dari besarnya peranan produk unggulan terhadap total perekonomian (Darmawansyah, 2003).

Konsep pembangunan sangat bervariasi menurut pemikiran beberapa tokoh ekonomi seperti Karl Marx (menulis pada abad terakhir) menggambarkan pembangunan sebagai perkembangan melalui serangkaian tahap sosial ekonomi yang berpuncak pada sosialisme yang mana masyarakat harus melewati masa perjalanan sejarah. Setiap tahap dalam perjalanan sejarah tersebut mewakili 'mode produksi' yang berbeda, dengan kata lain, terdapat tipe hubungan yang berbeda antara orang dan sumber daya dalam proses produksi. Sementara dari sudut pandang berbeda di jelaskan bahwa pembangunan sebagai pertumbuhan ekonomi yaitu pertumbuhan output nasional, konsumsi dan standar kehidupan yang mana diteliti oleh akademis dan beberapa karya para ekonom dan sejarawan ekonomi seperti (Lewis WA, 1954) dan (Walt W Rostow, 1960) dan mereka beranggapan Model pengembangan awal mencerminkan keyakinan bahwa akumulasi modal adalah kunci untuk pertumbuhan ekonomi. Selain dari dua penjelasan di atas mengenai pemikiran pembanguan ada beberapa konsep lain dan pemikiran mengenai pembangunan, seperti pembangunan sebagai modernisasi, sebagai perubahan struktur dunia, Pembangunan sebagai pertumbuhan dipimpin oleh pasar bebas, dan yang terahir pembangunan yang berfokus pada kemiskinan.

Menurut (Sutoro, 2015), pembangunan desa merupakan suatu upaya yang dilakukan demi peningkatan kualiatas hidup dan kehidupan masyarakat di suatu daerah dimana pembangunan desa dilakukan oleh seluruh lapisan baik pemerintah maupun masyarakat. Ungkapan pembangunan pedesaan dapat juga digunakan untuk merujuk pada proses perubahan dalam masyarakat pedesaan, yang tidak semuanya melibatkan tindakan pemerintah. Dalam hal ini, aktivitas pembangunan Pedesaan sebagai bentuk intervensi negara, harus dianggap hanya sebagai salah satu kekuatan untuk pembangunan itu sendiri, meskipun peran negara merupakan salah satu yang semakin penting, selain peran masyarakat pedesaan itu sendiri.

Asumsi yang digunakan para ekonom yaitu ketika pembangunan desa dilakukan maka kemiskinan akan turun secara otomatis, hal ini didasari karena ketika pembangunan desa dilakukan maka kebutuhan dasar orang miskin dalam hal makanan, kesehatan dan pendidikan, dan lain-lain tercukupi, selain itu produktivitas juga dapat meningkat. Hal ini sejalan dengan tujuan Pembangunan Milenium untuk mengurangi separuh jumlah orang yang hidup dalam kemiskinan pada 2015 menyoroti keharusan kemiskinan sebagai fokus kebijakan. Namun demikian, insiden dan tingkat keparahan kemiskinan untuk beberapa waktu akan terus lebih tinggi di daerah pedesaan dibandingkan dengan daerah perkotaan, sehingga meskipun jumlah orang perkotaan di dunia melampaui jumlah orang pedesaan sekitar tahun 2010, jumlah orang miskin pedesaan tetap lebih tinggi daripada jumlah orang miskin perkotaan (IFAD, 2010).

\section{METODE}

Jenis penelitian ini adalah penelitian kualitatif, penelitian ini menggunakan metode Participatory Learning Method dan Survey Development Research Method dengan teknik wawancara, angket dan observasi. Sumber data yang digunakan adalah Menteri Hukum dan HAM, Peraturam Menteri Dalam Negeri, RPJMD Gubernur Sumatera Utara, dan data langsung lapangan. 
Populasi penelitian ini yaitu seluruh produk unggulan di Indonesia dengan sampel Sumatera Utara. Jenis data yang digunakan dalam penelitian ini yaitu primer dan sekunder.

\section{HASIL DAN PEMBAHASAN}

\section{Regulasi Tentang Produk Unggulan Daerah Pemerintah Provinsi Sumatera Utara}

Pemerintah Provinsi Sumatera Utara menyatakan bahwa tidak ada peraturan yang saling bertentangan, bahkan saling mendukung terkait dengan Regulasi tentang Penetapan produk unggulan atau pengembangan produk unggulan atau penetapan industri prioritas atau sejenisnya. Peraturan yang saling mendukung tersebut misalnya adalah kesesuaian dengan (Presiden republik indonesia, 2015) tentang Rencana Induk Pembangunan Industri.

Selain itu kesesuaian peraturan juga meliputi Perda (Gubernur Sumatera Utara, 2018) tentang Rencana Pembangunan Industri Provinsi, Rencana Tata Ruang Wilayah Provinsi dan Rencana Tata Ruang Wilayah Kabupaten/Kota, visi dan misi kepala daerah, tugas pokok dan fungsi (tupoksi) Organisasi Perangkat Daerah (OPD) dan tertera pada dokumen RPJMD Provinsi atau Kabupaten/Kota dan Implementasi RPIP, pengembangan industri yang termasuk dalam wilayah pengembangan pusat industri.

Pemerintah Daerah merasa bahwa belum terjadi efektivitas pelaksanaan regulasi (SDM, kesesuaian kultur, pelayanan, pemanfaatan SDA) dimana Pemerintah Daerah belum memberikan insentif bagi industri yang melakukan pengembangan produk unggulan daerah. Namun Pemerintah Daerah sudah memfasilitasi promosi dan pemasaran produk unggulan daerah. Meskipun mereka belum paham apakah dalam Penetapan produk unggulan atau pengembangan produk unggulan atau penetapan industri prioritas atau sejenisnya telah berkoordinasi dengan berbagai pihak, dan apakah sudah memiliki nilai inovasi atau tidak.

\section{Kota Medan}

Berdasarkan hasil perjalanan dari penelitian diketahui hal terkait regulasi Kota Medan sebagai berikut:

1. Diketahui bahwa Regulasi tentang pengembangan produk unggulan Sumatera Utara masih mengacu pada Peraturan (Mendagri, 2014) tentang Pedoman Pengembangan Produk Unggulan Daerah.

2. Pemahaman Pemerintah Daerah terhadap regulasi dimaksud dalam konteks penelitian ini dikategorikan menjadi 4 bagian, yaitu:

1) pemahaman terhadap ketepatan regulasi (tidak bertentangan dan saling mendukung);

2) pemahaman terhadap disharmoni peraturan; dan

3) pemahaman terhadap kesesuaian norma dan ketepatan azas tata kelola.

Dinas Koperasi dan UKM Provinsi, Dinas Perindustrian dan Perdagangan, dan Dinas Tanaman Pangan dan Hortikultura Sumatera Utara menyatakan bahwa tidak ada peraturan yang saling bertentangan, bahkan saling mendukung terkait dengan Regulasi tentang Penetapan produk unggulan atau pengembangan produk unggulan atau penetapan industri prioritas atau sejenisnya, dinas Koperasi dan UKM Provinsi Sumatera Utara merasa bahwa sudah ada efektivitas pelaksanaan regulasi (SDM, kesesuaian kultur, pelayanan, pemanfaatan SDA) dimana Dinas Koperasi dan UKM Provinsi Sumatera Utara sudah memberikan insentif bagi industri yang melakukan pengembangan produk unggulan daerah yaitu yang bergerak dibidang Dinas Koperasi dan UKM, Industri bergerak dibidang kerajinan. Dinas Koperasi dan UKM Provinsi Sumatera Utara juga sudah memfasilitasi promosi dan pemasaran produk unggulan daerah yaitu Dalam bentuk: fasilitasi pameran di dalam dan luar daerah maupun luar negeri, fasilitasi penjualan 
offline (galeri) dan online, temu mitra/bisnis dengan negara, provinsi maupun usaha/perusahaan/instansi lain.

Begitu juga dengan dinas perindustrian dan perdagangan dan dinas tanaman pangan dan hortikultura yang menganggap Peraturan yang saling mendukung tersebut misalnya adalah kesesuaian dengan Peraturan dalam (Presiden Republik Indonesia, 2015) tentang Rencana Induk Pembangunan Industri, dan sesuai peraturan juga dengan (Gubernur Sumatera Utara, 2018) tentang Rencana Pembangunan Industri Provinsi, Rencana Tata Ruang Wilayah Provinsi dan Rencana Tata Ruang Wilayah Kabupaten/Kota, visi dan misi kepala daerah, tugas pokok dan fungsi (tupoksi) Organisasi Perangkat Daerah (OPD) dan tertera pada dokumen RPJMD Provinsi atau Kabupaten/Kota dan Implementasi RPIP, pengembangan industri yang termasuk dalam wilayah pengembangan pusat industri namun untuk regulasinya berbeda dengan dengan dinas koperasi dan umkm, dinas perindustrian dan perdagangan dianggap masih kurang efektif pada regulasi (SDM, kesesuaian kultur, pelayanan, pemanfaatan SDA) dimana Pemerintah Daerah belum memberikan insentif bagi industri yang melakukan pengembangan produk unggulan daerah. walaupun sudah memfasilitasi promosi dan pemasaran produk unggulan daerah. Dan untuk dinas tanaman pangan dan hortikultura menganggap kesesuaian peraturan dengan Keputusan (Menteri pertanian republik indonesia, 2018) tentang Lokasi Pengembangan Kawasan Pertanian, Rencana Tata Ruang Wilayah Provinsi dan Rencana Tata Ruang Wilayah Kabupaten/Kota, visi dan misi kepala daerah adapun visi dan misinya yaitu Misi Pertama yaitu mewujudkan masyarakat Sumatera Utara yang bermartabat dalam kehidupan karena memiliki iman dan taqwa, tersedianya sandang pangan yang cukup, rumah yang layak, pendidikan yang baik, kesehatan yang prima, mata pencaharian yang menyenangkan, serta harga-harga yang terjangkau.

\section{Kabupaten Labuhanbatu}

Pemerintah Kabupaten Labuhanbatu memiliki 2 regulasi untuk mendukung pengembangan produk unggulan berbasis Desa di Kabupaten Labuhanbatu, yaitu:

1. Keputusan Bupati Labuhanbatu Nomor 530/175/Dag.Ind/2017 tentang Penetapan Produk Unggulan Daerah Kabupaten Labuhanbatu yaitu mengenai kegiatan penelitian ini adalah: dijelaskan dalam (Perindustrian, 2014) dan (Mendagri, 2014) tentang Pedoman Pengembangan Produk Unggulan Daerah, selanjutnya menetapkan kerajinan dari lidi kelapa sawit; sirup nenas; tenun; terasi; stik ikan terubuk; kue jahe; dan handycraft (kerajinan dari kerta koran, kerajinan dari bahan acrilik berupa bros, tas, dan gantungan kunci) sebagai produk unggulan, sementara barang yang dihasilkan oleh para pelaku usaha kecil dan menengah yang dikembangkan dengan memanfaatkan sumber daya alam, SDM, dan budaya lokal yang mendatangkan pendapatan bagi masyarakat dan Pemerintah Daerah.

2. Peraturan Daerah Kabupaten Labuhanbatu Nomor tahun 2016 tentang Rencana Pembangunan Jangka Menengah Daerah Kabupaten Labuhanbatu Tahun 2016-2021. Poin penting dari RJMD di atas yang terkait dengan kegiatan penelitian ini bahwa: Pengembangan produk unggulan daerah di Kabupaten Labuhanbatu secara tersirat sesuai dengan misi Bupati, yaitu: Misi 4: membangun perekonomian yang kuat untuk menjamin pemerataan kesejahteraan masyarakat melalui Perluasan Lapangan Kerja, peningkatan kuantitas dan kualitas produksi pertanian, perkebunan, perikanan, peternakan, penguatan lembaga keuangan dan koperasi serta pengembangan potensi kawasan wisata. sasaran serta arah kebijakan yang ingin dicapai pada misi 4 adalah: meningkatnya kondisi perekonomian daerah; meningkatnya perekonomian yang berbasis potensi daerah; meningkatnya 
perekonomian melalui pengembangan Koperasi, UMKM dan Industri Kecil Menengah; pembangunan Industri berbasis potensi daerah; memperluas lapangan pekerjaan; serta mengembangkan potensi wisata daerah; Pengembangan produk unggulan daerah di Kabupaten Labuhanbatu didukung oleh Program dan Kegiatan di Organisasi Perangkat Daerah (OPD) teknis, seperti: Pertanian, Penelitian dan Pengembangan, Pangan, Koperasi, Usaha Kecil, dan Menengah, Perdagangan, Perindustrian, Koperasi, Usaha Kecil, dan Menengah, Tenaga Kerja, Pariwisata, Penanaman Modal, Program Peningkatan Promosi dan kerjasama Investasi.

Dinas Pemberdayaan Masyarakat dan Desa, BAPPEDA, Dinas Perindustrian dan Perdagangan Labuhan Batu menyatakan tidak ada peraturan yang saling bertentangan, bahkan saling mendukung terkait dengan Regulasi tentang Penetapan produk unggulan atau pengembangan produk unggulan atau penetapan industri prioritas atau sejenisnya. Rencana Tata Ruang Wilayah Provinsi dan Rencana Tata Ruang Wilayah Kabupaten/Kota, visi dan misi kepala daerah, tugas pokok dan fungsi (tupoksi) Organisasi Perangkat Daerah (OPD) dan tertera pada dokumen RPJMD Provinsi atau Kabupaten/Kota.

Organisasi Perangkat Daerah (OPD) sendiri juga merasakan kesesuaian terhadap peraturan yang ada sudah sesuai dengan norma dan ketepatan azas tata kelola, Pemerintah Daerah merasa bahwa sudah terjadi efektivitas pelaksanaan regulasi (SDM, kesesuaian kultur, pelayanan, pemanfaatan SDA) dimana Pemerintah Daerah sudah memberikan insentif bagi industri yang melakukan pengembangan produk unggulan daerah. Namun Pemerintah Daerah sudah memfasilitasi promosi dan pemasaran produk unggulan daerah begitu juga dengan penetapan produk unggulan atau pengembangan produk unggulan atau penetapan industri prioritas atau sejenisnya telah berkoordinasi dengan berbagai pihak, dan apakah sudah memiliki nilai inovasi atau tidak. Organisasi Perangkat Daerah (OPD) juga sudah mengetahui secara pasti apakah Penetapan produk unggulan atau pengembangan produk unggulan atau penetapan industri prioritas atau sejenisnya telah memberdayakan peran serta masyarakat dan potensi sumber daya alam, serta sudah mengetahui pasti apakah produk unggulan masing-masing daerah dapat memberikan kesempatan berusaha dan perluasan kesempatan kerja.

Berbeda hal menurut BAPPEDA. Menurut BAPPEDA bahwa pengembangan produk unggulan daerah belum menerapkan tata kelola yang baik. Hal ini diputuskan dengan pertimbangan bahwa rentetan pertanyaan selanjutnya (No. 9 s.d 12) adalah indikator-indikator tata kelola yang baik, yang notabenannya bahwa Pemerintah Daerah belum memenuhi indikator dimaksud, sehingga lebih dimungkinkan bahwa pengembangan produk unggulan daerah belum menerapkan tata kelola yang baik. BAPPEDA menambahkan bahwa selain Dinas Perindustrian dan Perdagangan, Organisasi Perangkat Daerah (OPD) lainnya adalah Dinas Koperasi dan UMKM, Dinas Pertanian, Dinas PMD. Menurut BAPPEDA bahwa pengembangan produk unggulan belum menggunakan teknologi yang efisien dan optimasi kinerja proses produksi. Menurut BAPPEDA bahwa pengembangan produk unggulan daerah belum dilakukan audit tata kelolanya serta tata kelola pemanfaatan sumberdaya alamnya, namun dalam pengembangan produk unggulan belum memiliki regulasi eco-product.

Menurut BAPPEDA dan Dinas Perindustrian dan Perdagangan bahwa Pemerintah Daerah belum memberikan insentif bagi industri yang melakukan pengembangan produk unggulan daerah. Namun, Pemerintah Daerah telah memberikan fasilitasi promosi dan pemasaran produk unggulan daerah dalam bentuk pameran produk unggulan daerah pada saat event Ulang Tahun Pemkab, Event Pekan Raya Sumatera Utara dan lain-lain. BAPPEDA juga belum berkoordinasi dengan berbagai pihak dan pengembangan produk belum memiliki nilai inovasi akan tetapi 
BAPPEDA menambahkan bahwa Pemerintah Daerah telah fasilitasi pelatihan-pelatihan dan permodalan bagi masyarakat.

\section{Kabupaten Mandailing Natal}

Diperoleh beberapa regulasi yang mendukung pengembangan produk unggulan berbasis Desa di Kabupaten Mandailing Natal, diantaranya:

1. Keputusan Bupati Mandailing Natal Nomor 050.13/585/K/2016 dalam (Balitbang pemprov sumut, 2019)tentang Produk Unggulan Daerah Kabupaten Mandailing Natal tahun 2016. Produk unggulan daerah (PUD) merupakan produk berupa barang maupun jasa yang dihasilkan oleh koperasi, usaha skala kecil dan menengah yang potensial dikembangkan dengan memanfaatkan semua sumberdaya yang dimiliki oleh daerah baik alam, manusia, maupun budaya lokal, serta mendatangkan pendapatan masyarakat maupun pemerintah sebagai kekuatan ekonomi bagi daerah dan masyarakat setempat sebagai produk yang potensi yang memiliki daya saing, daya jual dan daya dorong menuju dan mampu memasuki pasar global. Jenis komoditi produk unggulan daearah tersebut adalah: Gula Aren/Gula Semut, Anyaman Pandan, dan Bubuk Kopi;

2. Peraturan Bupati Mandailing Natal Nomor 14 tahun 2018 tentang Pedoman Pengembangan Produk Unggulan Daerah Tingkat Kecamatan di Kabupaten Mandailing Natal

3. Peraturan Bupati Mandailing Natal Nomor 28 tahun 2019 tentang Pengembangan Kopi sebagai Sentra

4. Peraturan Bupati Mandailing Natal Nomor 56 tahun 2016 tentang Kedudukan, Susunan Organisasi, Tugas dan Fungsi serta Tata Kerja Dinas Pertanian Kabupaten Mnadiling Natal;

5. Peraturan Daerah Kabupaten Mandailing Natal Nomor 1 Tahun 2017 Tentang Rencana Pembangunan Jangka Menengah Daerah Tahun 2016-202

Dinas Koperasi dan UKM, Dinas Pemberdayaan Masyarakat dan Desa, BAPPEDA dan dinas pertanian menyatakan bahwa mendukung terkait dengan Regulasi tentang Penetapan produk unggulan atau pengembangan produk unggulan atau penetapan industri prioritas atau sejenisnya. Dinas Koperasi dan UKM juga tidak paham mengenai Penetapan produk unggulan atau pengembangan produk unggulan atau penetapan industri prioritas atau sejenisnya ditetapkan dengan Peraturan di Daerah Kabupaten/Kota sesuai dengan ketentuan peraturan perundang-undangan dan juga Rencana Tata Ruang Wilayah Provinsi dan Rencana Tata Ruang Wilayah Kabupaten/Kota.

Organisasi Perangkat Daerah (OPD) juga merasakan bahwa peraturan yang ada sudah sesuai dengan norma dan ketepatan azas tata kelola, namun masih perlu peningkatan koordinasi dan kerjasama. Adapun Organisasi Perangkat Daerah (OPD) yang melakukan eksekusi terhadap perencanaan tersebut sebagai leading sektornya, selain Bappeda yang memang fungsinya sebagai perencana daerah yakni "Dinas Koperasi dan UMKM serta Perindustrian dan Perdagangan". Hal lainnya terkait kesesuaian norma dan ketepatan azas tata kelola yaitu daerah yang memiliki produk unggulan menggunakan teknologi yang efisien dan optimasi kinerja proses produksi dimana teknologi yang digunakan masyarakat adalah mesin batik dan tenun, mesin pengolah makanan seperti vacuum freyer.

Dinas Koperasi dan UKM serta dinas pemberdayaan masyarakat dan desa merasa bahwa sudah ada efektivitas pelaksanaan regulasi (SDM, kesesuaian kultur, pelayanan, pemanfaatan SDA) dimana Dinas Koperasi dan UKM Bergerak di bidang industri kerajinan memberikan insentif bagi industri yang melakukan pengembangan produk unggulan daerah. Organisasi Perangkat Daerah (OPD) juga sudah memfasilitasi promosi dan pemasaran produk unggulan daerah dimana 
Organisasi Perangkat Daerah (OPD) yang memberikan fasilitasi promosi dan pemasaran produk unggulan daerah adalah Dinas Koperasi dan UKM Provsu. Dalam bentuk: fasilitasi pameran di dalam dan luar daerah maupun luar negeri, fasilitasi penjualan offline (galeri) dan online, temu mitra/bisnis dengan negara, provinsi maupun usaha/perusahaan/instansi lain. Pengembangan produk unggulan telah membuka kesempatan berusaha dan perluasan kesempatan kerja bagi masyarakat. Pekerjaan yang ditimbulkan adalah penenun, penjahit, pemasak, kurir dan yang menjadi Potensi sumber daya alam di Sumatera Utara adalah pertanian seperti: kopi, teh, gambir, jahe. Menurut Dinas PMD bahwa potensi sumber daya alam di Kabupaten Mandailing Natal adalah: Serai Wangi, Gula Aren, Kopi, sehingga nantinya dampak positif yang ditimbulkan menurut BAPPEDA yaitu dengan pengembangan produk unggulan daerah akan meningkatkan kemakmuran dan kesejahteraan masyarakat secara berkeadilan yaitu dengan berkurangnya pengangguran diwilayah tersebut.

\section{Kabupaten Tapanuli Tengah}

Pemerintah Kabupaten Tapanuli Tengah memiliki beberapa regulasi untuk mendukung pengembangan produk unggulan berbasis Desa di Kabupaten Tapanuli Tengah, yaitu:

1. Keputusan Bupati Tapanuli Tengah Nomor 2113/BPTT/2016 tentang Produk Unggulan Daerah Kabupaten Tapanuli Tengah Tahun 2016.

2. Keputusan Bupati Tapanuli Tengah Nomor 2113/BPTT/2016 menetapkan beberapa produk unggulan daerah Kabupaten Tapanuli Tengah, disajikan dalam bentuk matriks berikut:

3. Peraturan Daerah Kabupaten Tapanuli Tengah Nomor 8 Tahun 2013 tentang Rencana Tata Ruang Wilayah Kabupaten Tapanuli Tengah Tahun 2013-2033.

4. Peraturan Daerah Kabupaten Tapanuli Tengah Nomor 8 tahun 2019 tentang Rencana Pembangunan Industri Kabupaten Tapanuli Tengah Tahun 2019-2039

5. Peraturan Daerah Kabupaten Tapanuli Tengah Nomor 5 tahun 2017 tentang Rencana Pembangunan Jangka Menengah Daerah Kabupaten Tapanuli Tengah Tahun 2017-2022.

Organisasi Perangkat Daerah (OPD) menyatakan bahwa tidak ada peraturan yang saling bertentangan, bahkan saling mendukung terkait dengan Regulasi tentang Penetapan produk unggulan atau pengembangan produk unggulan atau penetapan industri prioritas atau sejenisnya. Inti dokumen RPJMD tentang penetapan produk unggulan adalah arah kebijakan pembangunan tahun 2019 dalam RPJMD terkait dengan pembinaan, pelatihan dan peningkatan kapasitas UMKM, IKM dan Koperasi serta peningkatan daya saing produk unggulan yang dihasilkan, dan pengembangan pertanian organik dan produk unggulan daerah untuk mendukung agro industri. Adapun Penetapan produk unggulan ditetapkan dengan Keputusan Bupati Tapanuli Tengah Nomor 2113/BPTT/2016 tentang Produk Unggulan Daerah Kabupaten Tapanuli Tengah Tahun 2016. Penetapan produk unggulan atau pengembangan produk unggulan atau penetapan industri prioritas atau sejenisnya sesuai dengan Rencana Tata Ruang Wilayah Provinsi dan Rencana Tata Ruang Wilayah Kabupaten yaitu Peraturan Daerah Kabupaten Tapanuli Tengah Nomor 8 Tahun 2013 tentang Rencana Tata Ruang Wilayah Kabupaten Tapanuli Tengah Tahun 2013 - 2033.

Pemerintah Daerah memiliki perencanaan penetapan produk unggulan. Organisasi Perangkat Daerah (OPD) yang mengeksekusi perencanaan tersebut sebagai leading sector adalah: Dinas Perindustrian dan Perdagangan; Dinas Lingkungan Hidup; dan Dinas Pelayanan. Pengembangan produk unggulan belum menggunakan teknologi yang efisien dan optimasi kinerja proses produksi dan juga belum melakukan audit tata kelolanya serta tata kelola pemanfaatan sumberdaya alamnya. Begitu juga dengan penetapan produk unggulan yang belum 
memiliki regulasi eco-product atau sejenisnya sebagai bentuk kepedulian terhadap lingkungan hidup yang ramah lingkungan dan bebas bahan-bahan berbahaya

\section{Kabupaten Serdang Bedagai}

Diperoleh beberapa regulasi yang mendukung pengembangan produk unggulan berbasis Desa di Kabupaten Serdang Bedagai, diantaranya:

1. Kabupaten Serdang Bedagai pada tahun 2016 telah memiliki regulasi terkait pengembangan produk unggulan daerah dengan Keputusan Bupati Serdang Bedagai Nomor 448/050/2016 tanggal 30 Desember 2016.

Namun begitu masih terdapat beberapa kendala yang dihadapi pemerintah yang termuat dalam (Gubernur sumatera utara, 2018) mengenai Peraturan Daerah Provinsi Sumatera Utara Nomor 4 Tahun 2018 yaitu:

1. Pengembangan sektor hulu belum optimal bersinergi dengan pengembangan sektor hilir

2. Pengembangan produk bernilai tambah masih sangat terbatas dan terpaku pada beberapa jenis produk antara (produk setengah jadi tertentu), belum berkembang sesuai dengan potensinya dan belum sampai pada spesifik daerah

3. Sumber daya manusia (sektor hulu dan sektor industri) masih kurang dan harus ditingkatkan, juga pengorganisasian dan iklim usaha yang belum sepenuhnya mampu mengeksploitasi sumberdaya

4. Infrastruktur yang belum memadai dalam mendukung pengembangan industri lebih lanjut.

5. Sarana prasarana utilitas pasokan energy listrik dan harga gas yang terlalu tinggi merupakan salah satu faktor yang menghambat untuk peningkatan jumlah produksi

6. Pengembangan kawasan industri yang direncanakan belum sepenuhnya terealisasi

Meskipun masih terdapat kendala-kendala lainnya, namun secara garis besar keenam kendala tersebutlah yang menjadi faktor terbesar penghambat pengembangan produk unggulan Sumatera Utara berbasis Desa. Untuk itu regulasi (Mendagri, 2014) tentang pengembangan produk unggulan daerah diharapkan mampu mengatasi kendala-kendala di Sumatera Utara di mana, seluruh aparat pemerintah daerah ikut terlibat dalam kegiatan pengembangan ini.

Bagian Hukum Sekretariat, BAPPEDA, Dinas Pemberdayaan Masyarakat dan Desa serta Dinas pertanian Kabupaten Serdang Bedagai menyatakan bahwa tidak ada peraturan yang saling bertentangan, bahkan saling mendukung terkait dengan Regulasi tentang Penetapan produk unggulan atau pengembangan produk unggulan atau penetapan industri prioritas atau sejenisnya. Peraturan yang saling mendukung tersebut misalnya adalah kesesuaian dengan Bab V Pasal 5 Nomor 4 Huruf J yaitu Terbangunnya Dan Terpeliharanya Jaringan Irigasi Dalam Peningkatan Produktivitas Padi Hingga Mencapai 6,2 Ton Per Hektar.

Menurut Pemerintah Daerah pengembangan produk unggulan atau penetapan industri prioritas atau sejenisnya tidak sesuai dengan tupoksi Organisasi Perangkat Daerah (OPD). Adapun hak dan kewajiban serta wewenang Pemerintah Daerah terkait pengembangan produk unggulan yakni melindungi dan mempromosikan. Dalam potensi disharmoni diketahui tidak ada bagian yang bertentangan atau tumpang tindih antara pemerintah daerah kab/kota dengan provinsi.

Menurut Organisasi Perangkat Daerah (OPD), penetapan produk unggulan atau pengembangan produk unggulan atau penetapan industri prioritas atau sejenisnya telah menerapkan tata kelola yang baik dan Organisasi Perangkat Daerah (OPD) mana yang mengeksekusi perencanaan tersebut sebagai leading sektornya, selain Bappeda yang memang fungsinya sebagai perencana daerah yakni Pertanian, Ketapang, PUPR. Menurut Organisasi 
Perangkat Daerah (OPD) bahwa penetapan industri prioritas atau sejenisnya telah memiliki regulasi eco-product yaitu bebas pestisida.

Pemerintah Daerah juga memberikan insentif bagi industri yang melakukan pengembangan produk unggulan daerah yaitu Pemberian Bantuan Alsintan dan juga memberikan fasilitasi promosi dan pemasaran produk unggulan daerah tersebut dalam bentuk yakni Hope Shope dan Propapa-Disnaker. Penetapan produk unggulan atau pengembangan produk unggulan atau penetapan industri prioritas atau sejenisnya telah berkoordinasi dengan berbagai pihak yakni Provinsi, Doktan, Ormas, Organisasi Perangkat Daerah (OPD) dan Pemerintah Desa.

Dinas Koperasi dan UKM Provinsi Sumatera Utara merasa bahwa sudah ada efektivitas pelaksanaan regulasi (SDM, kesesuaian kultur, pelayanan, pemanfaatan SDA) dimana Dinas Koperasi dan UKM Provinsi Sumatera Utara belum memberikan insentif bagi industri yang melakukan pengembangan produk unggulan daerah. Organisasi Perangkat Daerah (OPD) juga sudah memfasilitasi promosi dan pemasaran produk unggulan daerah yaitu Pemerintah Daerah mewujudkan pameran pembangunan yang di isi pameran produk-produk unggulan dari masingmasing kecamatan.

\section{KESIMPULAN}

1. Regulasi tentang pengembangan produk unggulan Sumatera Utara masih mengacu pada Peraturan Menteri Dalam Negeri Republik Indonesia Nomor 9 tahun 2014 tentang Pedoman Pengembangan Produk Unggulan Daerah.

2. Pemahaman Pemerintah Daerah terhadap regulasi dimaksud dalam konteks penelitian ini dikategorikan menjadi 4 bagian, yaitu: 1) pemahaman terhadap ketepatan regulasi (tidak bertentangan dan saling mendukung); 2) pemahaman terhadap disharmoni peraturan; dan 3) pemahaman terhadap kesesuaian norma dan ketepatan azas tata kelola.

3. Informan tidak memahami beberapa pernyataan terkait isi regulasi yang diujukan oleh tim peneliti, untuk melaksanakan regulasi pengembangan produk unggulan daerah bukan menjadi tanggung jawab pemerintah pusat atau daerah .

4. Organisasi Perangkat Daerah (OPD) saja akan tetapi menjadi tanggung jawab beberapa Organisasi Perangkat Daerah (OPD) teknis lainnya, yang sifat kegiatannya terintegrasi, atau mungkin saja tidak/belum optimalnya sosialisasi regulasi dimaksud ke beberapa Organisasi Perangkat Daerah (OPD) lain yang dianggap juga memiliki tanggungjawab terhadap pengembangan produk unggulan daerah.

\section{REKOMENDASI}

1. Untuk Gubernur Sumatera Utara yaitu Perlu membuat Peraturan Gubernur tentang Penetapan dan Pengembangan Produk Unggulan Daerah Sumatera Utara.

2. Untuk Dinas Perindustrian Dan Perdagangan Provinsi Sumatera Utara, Perlu memetakan Produk Unggulan Daerah yang berpotensi untuk dikelola secara industrialisasi dengan skala nasional untuk dimasukkan sebagai salah satu Rencana Pembangunan Industri Produk Unggulan Daerah

3. Untuk Bupati Labuhan Batu, Karo, Serdang Bedagai, \& Tapanuli Tengah, Perlu membuat Peraturan Bupati tentang Pengembangan Produk Unggulan Daerah sebagai lanjutan Peraturan masing-masing Bupati tentang Penetapan Produk Unggulan Daerah

4. Untuk Bupati Dairi, Perlu membuat Peraturan Bupati tentang Penetapan Produk Unggulan Daerah

5. Untuk Bupati Labuhan Batu, Perlu menyusun ulang penetapan produk unggulan daerah dengan memasukkan beberapa potensi produk unggulan daerah lainnya dalam bentuk 
Peraturan Bupati yang baru

6. Untuk Dinas Koperasi \& UKM, Dinas Perindustrian \& Perdagangan di Provinsi dan Kabupaten, Mengurus HKI ke Direktorat Jenderal HKI Kemenkum HAM untuk menjamin orisinalitas Produk Unggulan Daerah, memetakan potensi PUD dalam bentuk jasa, dan mengaudit tata Kelola teknologi yang ramah lingkungan dan pemanfaatan SDA dalam pengembangan PUD

7. Solusi pemerintah yang menjadi kebijakan program ini adalah mengembangkan produk unggulan kawasan perDesaan melalui klasterisasi, menciptakan integrasi secara vertikal, dan melibatkan pihak swasta untuk industri pasca panen, sehingga produktivitas ekonomi perdesaan bisa ditingkatkan dan biaya produksi bisa ditekan serta keuntungan hasil panen bisa maksimal untuk masyarakat Desa.

8. Alasan diperlukannya regulasi pengembangan kopi sebagai produk unggulan di Kabupaten Dairi adalah bahwa kopi sebagai produk unggulan daerah perlu dikelola dan dikembangkan berbasis kondisi dan kekhasan daerah agar memiliki daya saing sehingga dapat berdampak pada peningkatan kesejahteraan masyarakat. Penyelenggaraan Otonomi Daerah menuntut adanya produk hukum daerah dalam memberikan perlindungan terhadap kopi sebagai produk unggulan daerah, maka perlu membentuk Peraturan Daerah/Peraturan Bupati/peraturan lainnya tentang Produk Unggulan Daerah.

\section{UCAPAN TERIMA KASIH}

Ucapan terima kasih kami kepada Badan Penelitian dan Pengembangan Provinsi Sumatera Utara yang telah memberikan anggaran dana penelitian.

\section{DAFTAR PUSTAKA}

Balitbang Pemprov Sumut. (2019). Pengembangan Klaster Inovasi Produk Unggulan Daerah (PUD). Medan.

Darmawansyah. (2003). Pengembangan Komoditi Unggulan Sebagai Basis. Ekonomi Daerah. Institut Pertanian Bogor.

Gubernur Sumatera Utara. (2018). Undang-Undang Nomor Rencana Pembangunan Industri Provinsi dan Medan.

Gubernur Sumatera Utara. (2019). Peraturan Daerah Provinsi Sumatera Utara Nomor 5 Tahun 2019 Tentang Rencana Pembangunan Jangka Menengah Daerah Provinsi Sumatera Utara Tahun 2019-2023. Medan.

IFAD. (2010) Rural Poverty Report 2011.

Khoirul Ahmadi. (2012). Mengembangkan Pendidikan Berbasis Keunggulan Lokal dalam KTSP. Jakarta: Pustakaraya.

Lewis WA. (1954). Economic Development with Unlimited Supplies of Labour, in Manchester School. Manchester, pp. 139-191.

Mendagri. (2014). Peraturan Menteri Dalam Negeri Republik Indonesia Nomor 9 Tahun 2014 Tentang Pedoman Pengembangan Produk Unggulan Daerah. Indonesia.

Menteri Pertanian Republik Indonesia. (2018). Keputusan Menteri Pertanian Republik Indonesia Nomor 472/Kpts/Rc.040/6/2018 Tentang Lokasi Kawasan Pertanian Nasional. Indonesia: Menteri Pertanian Republik Indonesia.

Perindustrian, U. (2014). UU_Perindustrian_No_3_2014.pdf. Indonesia.

Presiden Republik Indonesia. (2015). Peraturan Pemerintah Republik Indonesia Nomor 14 Tahun 2015 Tentang Rencana Induk Pembangunan Industri Nasional Tahun 2015-2035. Indonesia.

Setiawan, A. (2012) Konsep Urbanisasi, azise.blogspot. Available at: http://azise.blogspot.com/2012/11/konsepurbanisasi.html.

Sutoro (2015). Desa Membangun Indonesia. Yogyakarta: Forum Pengembangan Pembaharuan Desa (FPPD). Walt W Rostow. (1960). The Stages of Economic Growth. Cambridge: Cambridge at University Press. 